\title{
Religion and Violence: Thinking again about the Link
}

\author{
James Moore \\ Valparaiso University, Valparaiso, IN 46383-46385, USA; James.Moore@valpo.edu \\ Academic Editor: Steven Leonard Jacobs \\ Received: 28 March 2017; Accepted: 1 June 2017; Published: 12 June 2017
}

\begin{abstract}
This article is a contribution to a Special Issue on religion and genocide edited by Dr. Steven Jacobs. The aim of the article is to suggest a dimension of research not often considered to be part of the discussion. Because genocidal events have happened in conjunction with religious holidays, the article suggests that researchers must consider the role that worship and the texts of worship play in shaping the context for genocide.
\end{abstract}

Keywords: Holocaust; genocide; worship; Good Friday; Passover

\section{Introduction}

Several years ago, I wrote an essay that explored the relation between religion and religious leaders and the genocide in Rwanda (Moore 2009). At that time, I was struck by the extraordinary irony that the genocide began just three days after the Christian celebration of Easter. This is all the more remarkable since the missionary movement in Rwanda had successfully converted Rwandans so that as many 95\% were Christian and nearly 70\% were Roman Catholic at the time of the genocide. This cuts across all groups in Rwanda meaning that they would have been, most likely, sitting together in worship on Easter Sunday only for some to viciously engage in face to face genocide the following Wednesday. On the one hand, this seems completely counterintuitive. Even so, many of us who have studied genocides know that in fact the juxtaposition is not so strange after all. The texts that form the basis for the Easter celebration and for the whole range of holy days in the week of Easter, Holy week, include language that has been used to support violence in the past. In this essay I offer a think piece that extends the reflections of the earlier work (see appendix). ${ }^{1}$ Thus, this reflection will not be exploring research data, nor will the essay review the state of the research. Instead, I have been asked to offer theological insight into the link between genocidal violence and worship, specifically the texts of worship.

In that earlier essay, I suggested that an exploration is needed to show details about this connection. The question is, to what extent can we show that the texts of that Holy Week were such that they created a context for violence even while many of us might argue that Christianity should not be a religion of violence? This study would have to explore not only the biblical texts read those days but also the hymns sung and the sermons preached. An even more exhaustive study would require looking at patterns that developed over years that could set up a way of thinking that could be distorted into justifying violence, even genocide.

Naturally, such a study would require more than I could produce at that point. Also, experts from different disciplines should be engaged in the study. Thus, I could only suggest the directions a study

1 In fact, there is no evidence that any attention has been given to the connection between violence and worship. The book, Violence as Worship, uses worship as a metaphor in understanding violence but does not consider actual worship. The literature shows some sense that cults, worship and violence are linked but this is mostly related to brainwashing. Other articles are simply efforts to claim that worship is a context for reconciliation and peacemaking. 
could take and offer some evidence that the study was well worth undertaking. I was pleased when I delivered this paper at conference that the reception even from some from Rwanda reinforced my belief that the connection was real not so much as an abstraction but in the practical ongoing patterns of worship and church actions. We are also quite aware that clergy became involved in the genocide as well raising even more serious issues about the role of religion.

However, the Rwandan case is one but not the only one to study. We also know that the ethnic cleansing in the former Yugoslavia also drew clergy into the ranks of the genocidaires. It would clearly be of value to study this link between religion and mass violence in other genocides as well. We are surely aware of the way that religion connects with terrorism even as clergy from various religions and groups within religions play central roles. Even so, as I was asked to write again on this point, I was drawn back to the arena I am most familiar with, the Holocaust. Indeed, thinking about this led me to ask a question about the claims in Elie Wiesel's little book, Night (Wiesel 1960). Wiesel claims that the deportation of the Jews from Sighet, his home town, began on the first night of Passover. In fact, records show that this was exactly the case. Many have plenty to say about why the Nazis chose to act on holy days.

However, I wondered exactly what Christians were doing at that time. We are aware that often the celebration of Passover coincides with the Christian Holy Week. The Christian biblical texts in fact claim that Jesus ate his last meal with his disciples as a Seder meal. This means that the arrest, trial and crucifixion of Jesus is portrayed as occurring during the first days of Passover. This may or may not actually fit the facts, but the traditional belief is that this is the truth about Jesus' last days. For this reason, the liturgies for Holy Thursday assume that the meal was a Seder meal, that Good Friday, the day of Jesus' death was the following day in the Passover celebration (the rationale for removing the bodies from the cross before the Sabbath), and Easter the third day after this. If Christians were celebrating Holy Week as normal, they would have been in churches all four days of this remembrance hearing again the texts of the biblical story of Jesus' last days.

In fact, in 1944, the spring of the deportation of Hungarian Jews, Good Friday occurred on the day after the Passover Seder meal. There was an exact correlation between the celebration of the Passover and the days of Holy Week. For those of us involved in Holocaust studies, all of this is not very shocking anymore. The realities of Christian animosity toward Jews, displayed sporadically through various pogroms, are made especially clear in the annual celebrations of Holy Thursday, Good Friday and Easter. There are stories that Jews of every generation tell about the way that such liturgies can move some Christians to openly aggressive, even violent attacks of Jews, even when the relations are otherwise generally calm (something like Wiesel describes in his book).

My efforts have been to focus on re-thinking Christian theologies and teaching based on a response to the Holocaust. However, the compelling discovery that all of this reveals is that such an effort is not likely to have much impact if there is a lack of attention to Christian practice, particularly in worship. I was also moved to consider how not merely the biblical texts but also other texts of worship can have a role to play-hymns, anthems, prayers, confessions, sermons. Some of these texts are moveable, meaning that they may or may not be the same each year. Other texts are, or at least can be, set, meaning they repeat in the same form regularly.

Much depends on the nature of the Christian communities involved. The Christians in Hungary were and are of a diverse group, but the majority is Roman Catholic (there is actually also a significant Protestant, Lutheran population in Hungary as well). As with my reflections on Rwanda, this means that the worship style has a formal liturgy with texts that are set and repeated. We can do a preliminary investigation of this since we have some sense of texts that are likely to have been part of worship for a full range of churches that particular Spring. Of course, the point is much more extensive as Christian worship has a context not just theologically but also socially. We cannot single out religious practice from the factors that shape the lives of people otherwise. Nevertheless, there are some things we can say that lead us to understand the sort of study and possible change that is required to address the full scope of the link between religion and violence. 


\section{The Socioeconomic Context}

Sometimes, I am asked, “Why did the Jews reject Jesus?" For some Christians, asking this question seems natural since they have been nurtured on an idea that has been taught in various ways through centuries. This idea creates a picture of Jews actually thinking about Jesus and deciding to reject whatever Jesus is and stands for. It takes quite a lot to convince these individuals that the question is not only simplistic but mostly false. Indeed, those Christians who have taught and heard this idea through the centuries not only see this as an intellectual discussion but rather a personal affront. This is simply a piece of so much that could be labelled "the teaching of contempt", as it was by Jules Isaac (Isaac 1964).

I offer this note for two reasons. First, in much the same way any suggestion that the churches and members of those churches failed their moral obligation in not resisting the Nazi genocide clearly is also too simple. This is even more the case when speaking of specific locations like Sighet, the childhood home of Elie Wiesel. We cannot believe that the Nazis actually told the Christians of their midnight plans for deportation let alone waited for a reply before proceeding. Neither can we assume that these Christians simply knew what was to happen and openly chose not to do anything. This is quite apart from the question as to whether any of us would have acted differently. It is still troubling that Christians gave so little resistance overall. Nevertheless, no such explicit rejection or failure to act took place, at least not for the majority of Christians.

However, my comments on views of Jews openly rejecting Jesus speaks to the social context for action. Even if there might have been interaction, as Wiesel describes between the Jewish community of Sighet and the gentiles there, the patterns likely meant that these were very separate worlds. Christians would not have had in their awareness much of anything taking place in the Jewish communities as a rule. Thus, when the transports came and synagogues were being destroyed, it is not difficult to assume that Christians would have been generally unaware, in that way disinterested. They were prepared by their own teaching to have little concern for Jews. Even with this, there were some as Wiesel reports that did know and cared enough to warn Jewish leaders.

My point is that the Nazi decision to move the Jewish community on Passover was a devious and well-conceived plan because it coincided exactly with the Christian observance of Holy Week. Mainly it would be obvious that not only were Jews caught off guard because of their observance of Passover, but also Christians would have been completely distracted because of worship during Holy Week happening at exactly the same time. Clearly, knowledge would come after the fact, but there is little reason to believe that many Christians would be free to choose to intervene and resist. This all depends even on whether Christians would have been motivated to resist.

It is the irony of the narratives of Holy Week, for Christians, that central to the message is the message of forgiveness, but the emotions of the narrative have historically generated anger and resentment, even approaching violence. As some would fantasize about being at the cross jumping in to come to the aid of Jesus, these same activists would be motivated even more at this point in their worship year by anger at the projected enemies of Jesus, the Jews. The thrust of the passion narratives are unmistakable. The Christian gospel texts make Jews the enemies, responsible for the Crucifixion itself. Reacting to such texts, Christians would be primed to believe that the Jews rejected Jesus. Religious teaching would be a context that promotes violent response not through rational consideration but through deeply developed emotions.

\section{Where Does This Direct Us?}

As with my earlier reflections on Rwanda, I suggest a possible avenue of study that remains beyond the scope of what can be done in this essay. So much attention has been given to how religions are taught so that the centerpiece of the involvement of religions in violence has often been linked to ideas, more specifically to ideology. I and others have spent much energy making this case. This is likely true for so many cases we could examine-Nazi Germany, Rwanda, Bosnia, contemporary terrorist groups. Even so, I have argued that much of the impact of teaching comes through worship. 
Any study of religion and violence that ignores the role that worship plays in the larger picture may be missing a central factor.

It seems almost coincidental that the Hungarian deportations would begin on a Passover that immediately coincides with Good Friday. I hardly think that either was a coincidence in Nazi plans. More to the point though is that centuries of regular worship patterns, annual celebrations of Good Friday and Easter, shaped not only an ideologically fashioned worldview but also a deeply emotional reaction to the alien others. All of this is tied to a story that is more than just ideas. It is a story that is pictured, given full flesh and blood in so many ways.

Thus, an investigation of the relation of religion and violence needs those who can explore the way the texts of worship-hymns, prayers, as well as scriptures-embody ideas and images, encourage attitudes and emotions. The context of worship is the way that religious leaders not only influence the followers but also dramatically shape their attitudes over constant reinforcement through the years. For the active member, this means that these messages are sent every week and especially at those high moments, the high holidays, that centrally represent the heart and soul of any of the religions.

Conflicts of Interest: The author declares no conflict of interest.

\section{Appendix A}

I provide a sample of texts that represent what might have been part of worship for Good Friday. An analysis along the lines of what I am suggesting would need to consider the whole cycle of texts common for worship in churches such as Lutheran churches that are also prevalent in Hungary. The hymn below is a German hymn that could easily have been part of normal worship. The point is that religion impacts behavior through worship in many ways more significantly than through other forms of teaching. These texts do not account for the ways that homilies for the day and other symbolic displays for worship would also set the tone for the attitudes of worshippers. I offer these texts not as full proof but as a sample of what needs further study.

If we examine the language of the texts below, we can see themes that do not urge anti-Jewish thinking. On the other hand, the language does suggest that the death of Jesus was intensified by the implications of phrases like "By foes derided, by thine own rejected". This sort of picture does create a feeling of anger toward those who are seen as bringing on Jesus' suffering. Or as believers are led in prayer to say that Jesus was "willing to be betrayed and to be given to the hand of sinners" the worshipping congregation will again see the remembrance of Jesus' death in the context of betrayal and rejection. Hymns and prayers do not generally receive any form of interpretation or explanation that could remove the implicit anti-Judaism in the images of these texts. We cannot know how texts might have explicitly have been determined for the occasion of worship in those years of the Nazi deportations, but the point is that examination of liturgical texts should receive as much attention for revision as has been given to the teaching tools of the churches. The suggestion here is not that we know how texts might create a context for possible violence but that given our knowledge of genocide, we are challenged even more to eliminate any possible suggestion of teaching that sustains the long history of a "teaching of contempt".

\section{Two verses from a Sample Hymn:}

1. Ah, holy Jesus, how hast thou offended,

That we to judge thee have in hate pretended?

By foes derided, by thine own rejected,

O most afflicted!

2. Who was the guilty? Who brought this upon thee?

Alas, my treason, Jesus, hath undone thee! 
'Twas I, Lord Jesus, I it was denied thee;

I crucified thee.

From: The Lutheran Book of Worship. Philadelphia: Fortress Press, 1978, hymn 123.

\section{A Prayer for Good Friday:}

Almighty God, we ask you to look with mercy on your family, for whom our Lord Jesus Christ was willing to be betrayed and to be given to the hand of sinners and to suffer death on the cross, who lives and reigns with you and the Holy Spirit, one God, forever and ever.

From: The Lutheran Book of Worship. Philadelphia: Fortress Press, 1978, p. 20.

The Gospel text for Good Friday:

John 19:

\section{The Crucifixion of Jesus}

So they took Jesus; ${ }^{17}$ and carrying the cross by himself, he went out to what is called The Place of the Skull, which in Hebrew is called Golgotha. ${ }^{18}$ There they crucified him, and with him two others, one on either side, with Jesus between them. ${ }^{19}$ Pilate also had an inscription written and put on the cross. It read, 'Jesus of Nazareth, the King of the Jews.' ${ }^{20}$ Many of the Jews read this inscription, because the place where Jesus was crucified was near the city; and it was written in Hebrew, in Latin, and in Greek. ${ }^{21}$ Then the chief priests of the Jews said to Pilate, 'Do not write, "The King of the Jews", but, "This man said, I am King of the Jews." '22 Pilate answered, 'What I have written I have written.' ${ }^{23}$ When the soldiers had crucified Jesus, they took his clothes and divided them into four parts, one for each soldier. They also took his tunic; now the tunic was seamless, woven in one piece from the top. ${ }^{24}$ So they said to one another, 'Let us not tear it, but cast lots for it to see who will get it.' This was to fulfil what the scripture says,' They divided my clothes among themselves, and for my clothing they cast lots.' ${ }^{25}$ And that is what the soldiers did.

Meanwhile, standing near the cross of Jesus were his mother, and his mother's sister, Mary the wife of Clopas, and Mary Magdalene. ${ }^{26}$ When Jesus saw his mother and the disciple whom he loved standing beside her, he said to his mother, 'Woman, here is your son.' ${ }^{27}$ Then he said to the disciple, 'Here is your mother.' And from that hour the disciple took her into his own home.

The New Revised Standard Version (Anglicized Edition), copyright 1989, 1995 by the Division of Christian Education of the National Council of the Churches of Christ in the United States of America.

The author was enlightened by the following books.

Cobban, Helena. 2005. Religion and Violence. Journal of the American Academy of Religion 73: 1121-39.

Deak, Istvan. 1996. With God on Their Sides. New Republic 215: 31-35.

Jacobs, Steven Leonard. 2010. Genocidal Religion. Journal of Hate Studies 9: 221-35.

Klippenberg, Hans, and Brian McNeil. 2011. Worship as Violence: Religious Wars in the Age of Globalization. Palo Alto: Stanford University Press.

Longman, Timothy. 2001. Church Politics and the Genocide in Rwanda. Journal of Religion in Africa 31: 163-86.

Victor, George. 2004. Fundamentalism, the Holocaust and Other Genocide. Journal of Psychohistory 31: 452-76. 


\section{References}

Isaac, Jules. 1964. The Teaching of Contempt: Christian Roots of Antisemitism. New York: Rhinehart and Winston. Moore, James F. 2009. The Accountability of Religion in Genocide. In Confronting Genocide. Edited by Steven Leonard Jacobs. Lanham: Lexington Books, pp. 65-76.

Wiesel, Elie. 1960. Night. New York: Bantam.

(c) (2)

(C) 2017 by the author. Licensee MDPI, Basel, Switzerland. This article is an open access article distributed under the terms and conditions of the Creative Commons Attribution (CC BY) license (http://creativecommons.org/licenses/by/4.0/). 